\title{
EVALUATION OF BIOLOGICAL AND PHYSICOCHEMICAL RELATIONSHIPS AS INDICATORS OF WATER QUALITY IN TOLTÉN RIVER BASIN, ARAUCANÍA, CHILE: PRELIMINARY RESULTS
}

\author{
CLAUDIA JIMENA GUERRERO-JIMÉNEZ ${ }^{a *}$, CLAUDIA LORENA RABERT ${ }^{a}$, ALBERTO SÁEZ-ARTEAGA ${ }^{a}$, \\ NICOL LONCOMAN ${ }^{b}$, GERALDINE TORRES ${ }^{b}$, TOMAS FLORES ${ }^{b}$, FRANCISCO LLANQUÍN-ROSAS ${ }^{c}$, \\ MARÍA LUISA VALENZUELA ${ }^{d}$ AND ROBERTO MORENO ${ }^{e}$
}

\author{
aInstituto de Ciencias Biomédicas. Facultad de Ciencias de la Salud. Universidad Autónoma de Chile. Avenida Alemania 01090. \\ Temuco Región de la Araucanía Chile \\ ${ }^{b}$ Carrera Nutrición y Dietética. Facultad de Ciencias de la Salud. Universidad Autónoma de Chile. Avenida Alemania 01090. \\ Teтuco Región de la Araucanía Chile \\ ${ }^{c}$ Departamento de Ciencias Ecológicas, Universidad de Chile, Las Palmeras 3425 Ñuñoa, Santiago, Región Metropolitana, Chile \\ dInstituto de Ciencias Químicas Aplicadas. Facultad de Ingeniería. Universidad Autónoma de Chile. Avenida Alemania 01090. \\ Temuco Región de la Araucanía Chile \\ ${ }^{e}$ Grupo de Investigación en Gestión Sostenible de los Recursos Naturales, Instituto Iberoamericano de Desarrollo Sostenible (IIDS), Universidad Autónoma de \\ Chile. Avenida Alemania 01090.Temuco Región de la Araucanía Chile.
}

\begin{abstract}
River basins play a critical role in ecosystem services and their status regulate the associated productivity. Anthropogenic activities along with other environmental perturbation influence the vulnerability level of that important water resource, disturbing in a short time, water quality. The aim of this work is to generate an approach to Toltén basin characterization with benthonic macroinvertebrates, physicochemical and bacterial components as indicators of variation in water quality close to human populations and the sectors furthest from them, selecting for this purpose two areas (up and downstream of the basin). We used an ANOSIM two-way analysis to relate abiotic and biotic data and for diversity and biotic index (ChBMWP) we analyzed the benthic macroinvertebrate composition. A principal component analysis for environmental variables strongly separated the analyzed zones by season as the first principal component, showing a clear increase in temperature and electrical conductivity values in spring season. Meantime the $\mathrm{pH}$ parameter was observed with interesting variation for longitudinal gradient with incremental values in upstream area. The biotic indexes applied to the samples between seasons reflexes a similar diversity between analyzed sites in upstream with no differences showing a low diversity of macroinvertebrates. However, a significant increase was detected during spring in downstream zone. On the other hand, Pseudomonas genus increase between the most representative microbiological genera in the basin. Our results reinforce the importance not only of frequent seasonal monitoring program but also the critical role of collecting data on total transect basin length to regulate the human activities associated to basin and to protect the water quality.
\end{abstract}

Keywords: Macroinvertebrates, river basin, water quality, abiotic parameters.

\section{INTRODUCTION}

Rivers and streams are vital ecosystems that sustain the life of humans and animals [1]. In many countries, rivers are essential water sources for domestic, agricultural, industrial, and recreational activities [2], [3] and constitute some of the most diverse and heterogeneous ecosystems on the earth [4], [5]. Water systems are affected by land cover change, productive systems, and anthropogenic activities [6].

The characteristics of river basins depend on many factors, including the use of land, climate, and soil conditions. However, variations in water quality associated with these types of land use have not yet been determined and fully quantified [7], [8]. Recently, special attention has been given to hydrological characteristics, by examining the relationships between land, uses and water quality at various scales [9]. Water quality parameters in aquatic systems are closely linked to the proportions or types of land use within a watershed [8]. The assessment of water quality has traditionally been based on physicochemical and bacteriological analyses [10], [11]. However, in recent years, many countries have accepted the inclusion of macroinvertebrate fauna to evaluate the quality of aquatic ecosystems as a complement to the physicochemical parameters [12]. The characteristics of these organisms as indicators of quality of water are that these are abundant, widely distributed and easy to collect; most of them are sedentary which allow to reflect the conditions of their habitat. They are relatively easy to identify; representing the effects of short-term environmental variations; providing information to integrate cumulative effects [13] and presenting different responses to pollution.

The northern Patagonian Chilean Rivers ( $38-41^{\circ} \mathrm{S}$ ) are characterized by their origin from lake effluents [14]. The Toltén river is located in the young Araucanía region and originates in the Villarrica lake [14], [15]; its course includes zones with low levels of human intervention, close to its origin, and zones with increasing of human interference from the towns of Pitrufquén, and Freire [14]. After 137 years, the Araucanía region needs to have an inventory of its macrofauna of benthic invertebrates as a baseline to evaluate the impact of the anthropogenic activities growth and to generate conservation measures for the ecosystem of the rivers of the Toltén river basin [16].
The demographic growth of cities is a problem that affects the use and quality of water in nearby rivers. In the Araucanía region, the towns have had a significant demographic growth, so the use of the basin for various human activities and the increase in animal and human fecal matter influence the water quality of the Toltén river basin. Our objective was characterized with biological (macroinvertebrates), microbiological, and physicochemical indicators the variation in water quality close to human populations and the sectors furthest from them.

\section{EXPERIMENTAL}

\subsection{Study area and samples collection}

Sampling sites covered the length of the river basin, considering one in the upper zone of the basin (two sites, upstream), and another in rural area, close to the towns of Pitrufquén and Freire, the downstream zone (three sites) (figure 1). The basin has an area of about $8,040 \mathrm{~km}^{2}$ and lies between latitude $37^{\circ} 35^{\prime}$ and $39^{\circ} 35^{\prime}$ South and longitude $72^{\circ} 28^{\prime}$ and $73^{\circ} 04^{\prime}$ West [17]. Additional data of morphometric and climatic features of the basin [18] are showed in table 1. Two collection times were done, the first during Chilean winter and second in spring period in 2019.

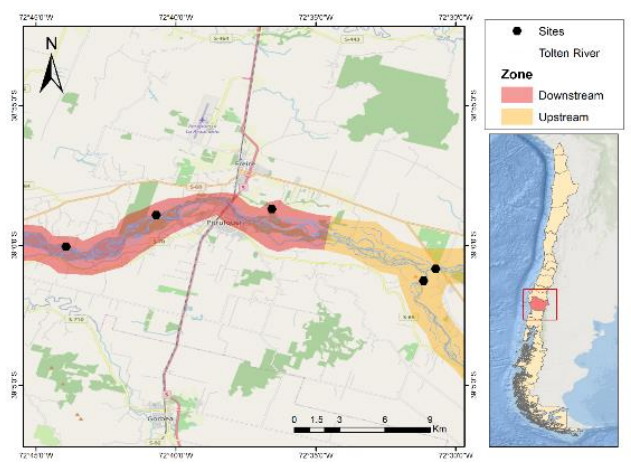

Figure 1. Geographic location of study area in Toltén River. 
Table 1. Morphometric and climatic features of Toltén basin.

\begin{tabular}{|l|l|}
\hline Parameter & Value or category \\
\hline Geology & $\begin{array}{l}\text { Sedimentary Rocks of the Pleistocene in low } \\
\text { section of the basin } \\
\text { Sedimentary rocks of the Pleistocene-Pliocene in } \\
\text { high section of the basin }\end{array}$ \\
\hline Predominant weather & $\begin{array}{l}\text { Warm rainy temperate with Mediterranean } \\
\text { influence (low and medium section of the basin) } \\
\text { and Cold rainy temperate with Mediterranean } \\
\text { influence (high section of the basin) }\end{array}$ \\
\hline Basin length $(\mathrm{km})$ & 135 \\
\hline Drainage basin & Exorheic \\
\hline River debouch & Pacific Ocean \\
\hline *Average water flow $\left(\mathrm{m}^{3} \mathrm{~s}^{-1}\right)$ & 354 \\
\hline *Precipitation $\left(\mathrm{mm}\right.$ year $\left.{ }^{-1}\right)$ & 979.8 \\
\hline *Average temperature $\left({ }^{\circ} \mathrm{C}\right)$ & 11.1 \\
\hline
\end{tabular}

*Source: Center for climate and resilience research for year 2019.

\subsection{Chemical Analysis}

In situ data was registered for physical and chemical characteristics (Conductivity, $\mathrm{pH}$ and temperature) were measure at each period (winter and spring) with multiparameter sonde EZDO 7200 model and the values were taken in triplicate. In table 1, we can observe the average values of the aforementioned variables obtained at each sampling sites corresponding to the upstream (S1 and S2) and downstream (S3, S4 and S5) zone.

Table 1. Sampling sites and average values $(n=3)$ of the main physical-chemical variables observed in two seasons (winter and spring) in Toltén river.

\begin{tabular}{|c|c|c|c|c|c|}
\hline Season & Zone & Sites & $\mathrm{pH}$ & Conductivity $(\mu \mathrm{S} / \mathrm{cm})$ & $\mathbf{T}\left({ }^{\circ} \mathbf{C}\right)$ \\
\hline \multirow{15}{*}{ Winter } & \multirow{6}{*}{ Upstream } & S1 & 6.52 & 38 & 12.78 \\
\hline & & S1 & 7 & 33 & 11.14 \\
\hline & & S1 & 7.03 & 26 & 11 \\
\hline & & S2 & 6.6 & 21 & 10.6 \\
\hline & & S2 & 6.8 & 22 & 9.7 \\
\hline & & S2 & 6.97 & 20 & 10 \\
\hline & \multirow{9}{*}{ Downstream } & S3 & 7.32 & 70 & 12.5 \\
\hline & & S3 & 7.27 & 73 & 11.3 \\
\hline & & S3 & 7.27 & 69 & 10.7 \\
\hline & & S4* & - & - & - \\
\hline & & S4* & - & - & - \\
\hline & & S4* & - & - & - \\
\hline & & S5 & 7.01 & 52 & 10.4 \\
\hline & & S5 & 7.14 & 48 & 10.5 \\
\hline & & S5 & 7.03 & 56 & 10.2 \\
\hline \multirow{15}{*}{ Spring } & \multirow{6}{*}{ Upstream } & S1 & 6.36 & 258 & 17 \\
\hline & & S1 & 6.6 & 285 & 15.4 \\
\hline & & S1 & 6.42 & 278 & 16.1 \\
\hline & & S2 & 7.35 & 257 & 15.5 \\
\hline & & S2 & 7.49 & 263 & 13.8 \\
\hline & & S2 & 7.41 & 252 & 14.5 \\
\hline & \multirow{9}{*}{ Downstream } & S3* & - & - & - \\
\hline & & S3* & - & - & - \\
\hline & & S3* & - & - & - \\
\hline & & S4 & 6.45 & 241 & 16.4 \\
\hline & & S4 & 6.69 & 246 & 15.4 \\
\hline & & S4 & 6.61 & 249 & 16.5 \\
\hline & & S5 & 7.48 & 266 & 15.1 \\
\hline & & S5 & 7.54 & 279 & 14.6 \\
\hline & & S5 & 7.52 & 265 & 14.9 \\
\hline
\end{tabular}

* Inaccessible point for climatic conditions, data did not record.

\subsection{Macroinvertebrates samples}

To collect and obtain a quantitative measure of the densities of benthic macroinvertebrates, a sample was taken with a Surber network of $0.30 \times 0.30 \mathrm{~m}$ $\left(0.09 \mathrm{~m}^{2}\right)$ with a pore size of $250 \mu \mathrm{m}$. Two randomized samples distributed among the different microhabitats were taken at each site. The collected material was deposited in polyethylene bottles and fixed in $96 \%$ ethanol.
The samples were transferred to laboratory where they were identified at the lowest possible taxonomic level using a stereoscopic magnifying glass and identification keys [19], [20], [21], [22]. Richness, density and biological diversity indices were calculated. Additionally, with the identified taxa, the biotic index for Chile ChBMWP proposed by Figueroa [23] was calculated to obtain an approximation to the water quality of the System.

\subsection{Isolation and identification of culturable bacteria}

Collection of most representative gram-negative bacteria of the basin were performed using the standard membrane filtration (MF) technique, three technical replicates were done for each site. Ten milliliters were analyzed by the single step direct MF technique with MacConkey agar (Becton Dickinson) and membrane filters ( $0.45 \mu \mathrm{m}$ pore size; Gelman, Ann Arbor, Mich.).

The differential colonies isolated on MacConkey agar were purified by several isolations on the same culture medium and pure cultures were preserved at $-80{ }^{\circ} \mathrm{C}$ in nutritive broth supplemented with $15 \%$ (v/v) glycerol. Total DNA was extracted from each differential colony isolated using DNeasy UltraClean Microbial Kit (Qiagen, USA) according to the manufacturer's directions and delivered to Macrogen S.A. (Seoul, Korea) for sequencing, using the universal primers 27F (5'-AGAGTTTGATCCTGGCTCAG-3') and 1492R (5'GGTTACCTTGTTACGACTT-3'), targeting the 16S rRNA region. For identification, the amplified sequences were BLAST-searched at (http://www.ncbi.nlm.nih.gov/).

\subsection{Data Analysis}

An analysis of variance (ANOVA) was performed to determine significant differences between the season (winter-spring) and study zone factors (upstreamdownstream) with the values of the in situ physicochemical parameters. An anova with the same factors (season-zone) was performed for the biotic factors.

To observe the environmental variables in a multivariate space, an ordination analysis was carried out by means of a principal component analysis (PCA) using the physical and chemical data measured in situ. Prior to the analysis, the data of the environmental matrix were normalized. After the analysis, the structure of the data and the relationship between the variables and the sites were observed.

For macroinvertebrates, a two-way similarity analysis (ANOSIM two-way) was performed, at the temporal and site level to determine the existence of groups in the structure of the community data. Prior to the analysis, the data were transformed using a square root, later a Bray-Curtis similarity matrix was calculated. Both the principal component analysis and the similarity analysis were performed using the PRIMER 7 statistical software with the PERMANOVA + extension [24], [25].

\section{RESULTS AND DISCUSSION}

\subsection{Physical and Chemical Parameters}

Averages of the main abiotic parameters such as $\mathrm{pH}$, temperature and conductivity were determined both in winter and spring season and in upstream and downstream zones (figure 2). Of all the variables measured, temperature and conductivity showed a significant increase in the values during spring with respect to winter in both sampling zones. These results are expected when the temperature increases and the solubility of the ions decreases, increasing the conductivity [26-27]. The $\mathrm{pH}$ values did not present statistical differences with respect to the zone or the season, observing the lowest value in the winter season (6.82) in the upstream zone, while the highest value was registered in the same season in the downstream zone (7.1).
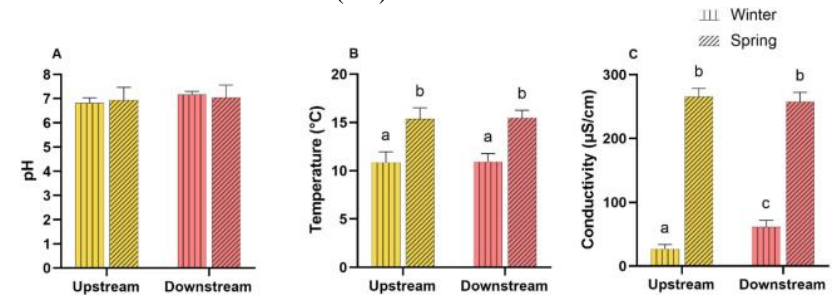

Figure 2. Main environmental variables obtained in downstream (red) zone and upstream (yellow) zone in different seasons (winter-spring). (A) $\mathrm{pH},(\mathrm{B})$ temperature and $(\mathrm{C})$ conductivity. The values correspond to the mean \pm standard deviation (SD), $\mathrm{n}=6$ samples in each zone. Different letters indicate significant differences $(P<0.05)$. 
With the ordering of the data in a multivariate space with the environmental variables (figure 3), it is possible to observe that the sites of the zone are separated by seasons for the first principal component. In spring, temperature and electrical conductivity are higher compared to the winter season. For the second main component, the $\mathrm{pH}$ clearly shows a gradient in spring across the sites, unlike in winter where the dispersion pattern is lower on this axis.

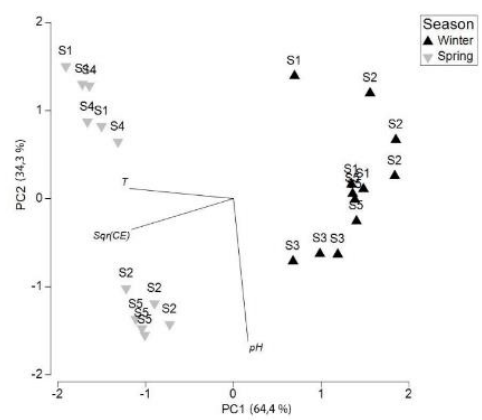

Figure 3. Principal components analysis (PCA) biplot of environmental variables in relation to along sampling sites in a section of Toltén river (the first two axe explain $98.7 \%$ of the total variance).

In general, the conductivity values showed levels suitable for water quality standards [28], [29] with a difference between winter and spring, which can be explained by the effect of rainfall, as indicated by Urrego et al. [30]. Previous studies done in Toltén basin showed a similar behavior in chemical variables [31], [32]. According to data reported during 2004 and 2013 and the current collected in this study (2019), the conductivity values has remained constant during winter season with a flat central trend of $65 \mu \mathrm{S} / \mathrm{cm}$. However, the data collected during spring, independent of the analyzed site, exhibit an important increase. The higher conductivity registered in downstream area in winter season, may be due to problems associated with contamination, either by agricultural uses that provide less coverage to the water course and greater habitability of surrounding areas [33], [34]. Meanwhile, for $\mathrm{pH}$ parameter, a similar influence of sites in $\mathrm{pH}$ level was reported in the Toltén basin [31], [32], where sites near to headwater stream (upstream) showed $\mathrm{pH}$ values below or close to 7.0 and sites near to mouth or delta section (downstream) showed $\mathrm{pH}$ values above to 7.0. The influence of the season also was observed, with an increase of the $\mathrm{pH}$ values with most temperate conditions [32].

\subsection{Macroinvertebrate community}

The specific richness (S) (figure 4A) presents similar values between the seasons of the upstream zone, as well as the downstream zone during winter. However, a significant increase is observed during spring in the downstream zone, compared to other zone and seasons. Behavior patterns like that observed in specific richness $(\mathrm{S})$ were obtained in Shannon diversity index $(\mathrm{H})$ and abundance $(\mathrm{N})$ (figure 4B, C). Highest values were established in the spring season in the downstream zone, observing statistical differences. The Pielou equity index $\left(\mathrm{J}^{\prime}\right)$ (figure $4 \mathrm{D}$ ) presented similar values between seasons in each of the sampling zones.
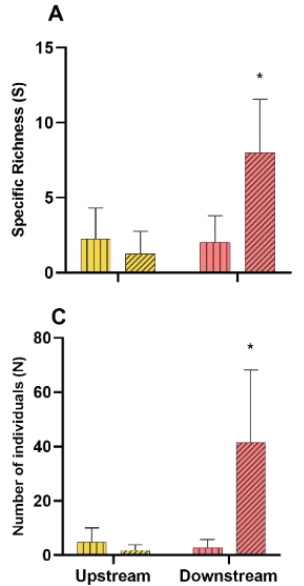
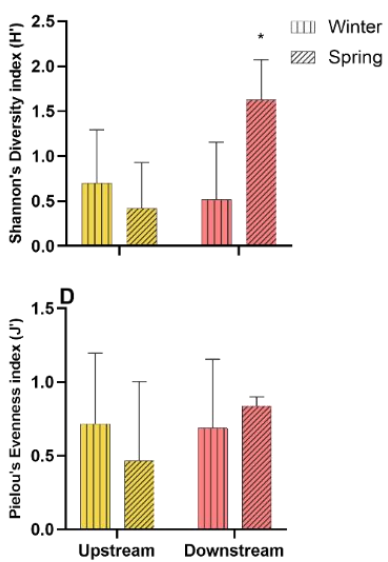

Figure 4. Diversity values and indices calculated in downstream (red) and upstream (yellow) zones in different seasons (winter-spring). A) Specific richness, B) Shannon diversity index, C) Abundance, and D) Pielou index. Asterix (*) represent statistically significant differences between samples $(p<0.05)$. In all the graphs, the bars represent mean \pm standard deviation (SD).

The Shannon index shows a low value, less than 2, which implies a low biodiversity of macroinvertebrates [35] especially in upstream area, situation that can be explained because generally the headwaters and first sections of the basins have less diversity than the middle of the main river channel [33]. Despite this common low diversity between upstream and downstream areas, the data collected in spring at downstream area showed a significant differences between the other points analyzed, this situation could be explain by the nearness to urbanized territories, influence of residual discharges, less coverage and higher environment impact [36], [32], [37].The richness and diversity show a similar relationship to that of the Shannon index, showing low values, slightly differentiated with greater diversity in downstream area, with a spring effect that increases the difference. Regarding the Pielou index, it shows similar trends to the Shannon index without significant variation as in other studies [38], [39], [40]. Regarding its absolute value, a high equity is visualized (values above 0.5), showing a high equality of presence of taxa [41], [42] in these periods, except in the winter season in the upstream area.

Within the macroinvertebrate community, the taxa with the highest abundance among the zones were Nousia cf minor, Antarctoperla sp and Limnoperla cf jaffueli. The taxa with less occurrence are the species of the genus Gigantodax $s p$, Parametriocnemus $s p$, and the taxa corresponding to the family Tubificidae, taxa of the class Collembola and the family Planaridae. According to the two-way ANOSIM analysis, there was no grouping between seasons for macroinvertebrates (ANOSIM $\mathrm{R}=0.5, \mathrm{p}=0.074$ ), but there was a local grouping of sites (ANOSIM R $=0.35, p=0.013$ ). The community structure can be seen in Figure 5, where for each site (S1, S2 upstream zone and S3 S4 S5 downstream zone), the community structure varies along the longitudinal gradient of the Toltén river section.

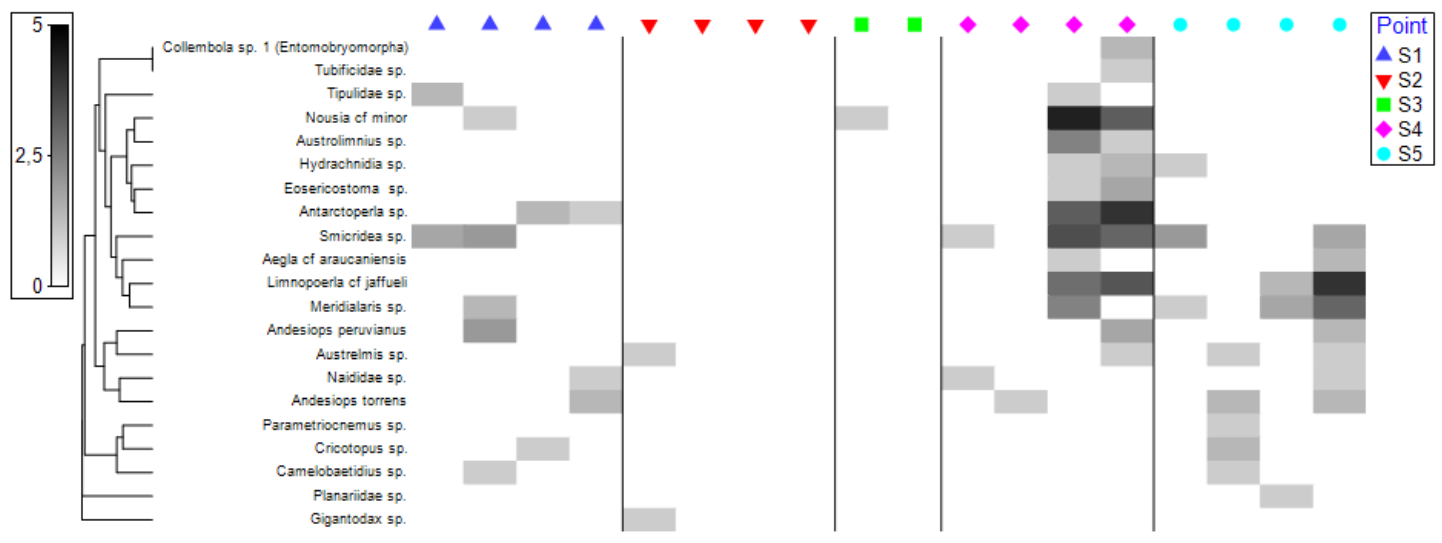

Figure 5: Macroinvertebrate community structure along the longitudinal gradient of the Toltén River basin. S1-S2 correspond to the upstream zone and S3-S4-S5 to downstream zone. The gray scale represents the number of individuals for that taxon (dark major, light gray minor). 
With community data, values of the biotic index were obtained at the family level adapted for Chile (IBFCh) (Table 2). A variation in the estimated water quality with biondicators is observed between seasons, where in spring the study sites reached a Class I, that is, of very good quality, while in winter the sites reached Class III, which is interpreted as regular water quality.

Table 2. Value of the adapted Biotic Index for Chile (IBFCh), estimated for each of the study sites between seasons.

\begin{tabular}{|c|c|c|c|c|}
\hline \multirow{2}{*}{ Site } & \multicolumn{2}{|c|}{ Winter } & \multicolumn{2}{c|}{ Spring } \\
\cline { 2 - 5 } & IBFCh & Class & IBFCh & Class \\
\hline S1 & 3,62 & I & 3,71 & I \\
\hline S2 & 5,33 & III & - & - \\
\hline S3 & 2 & I & - & - \\
\hline S4 & 5 & III & 2,65 & I \\
\hline S5 & 4,39 & II & 2,13 & I \\
\hline
\end{tabular}

\subsection{Identification of culturable bacteria}

The presence of some bacteria species poses serious concerns for the quality of aquatic systems as well as for human health, especially when sediments undergo re-suspension due to both natural and anthropogenic disturbances [43]. However, the limitation to develop the capacities to elucidate the functional bacteria in natural environments is remarkably, mainly because most of the microbial diversity cannot be cultivated and remains inaccessible [44]. It is well accepted that cultivation of bacteria on artificial media accounted for only less than $10 \%$ of bacterial cells in natural environments [45]. The analysis of bacterial diversity species in the basin area under study, using cultivation and isolation microbiological techniques, allow us identified eleven representative bacterial strain (table 3), where the most important genera was Pseudomonas with a $64 \%$ of representatively. The homology sequence analysis displayed a least a $98.76 \%$ sequence similarity with reference sequences in database.

Table 3. Identification of bacteria strains isolated from water samples of Toltén basin based on BLAST analysis of the 16S rRNA a gene sequences database setting in the NCBI GenBank.

\begin{tabular}{|c|l|c|c|}
\hline $\begin{array}{c}\text { Microbial } \\
\text { isolated code }\end{array}$ & \multicolumn{1}{|c|}{ Nearest homologue sequences } & $\begin{array}{c}\text { Accession } \\
\text { number }\end{array}$ & $\begin{array}{c}\text { Sequence } \\
\text { identity\% }\end{array}$ \\
\hline C2 & Pseudomonas extremaustralis strain BF11 & MT441542.1 & $99.4 \%$ \\
\hline E1 & Psychrobacter sp. Td-2 & KX230037.1 & $100 \%$ \\
\hline E2 & Pseudomonas baetica strain cqsm_h4 & MN826557.1 & $99.8 \%$ \\
\hline E5 & Pseudomonas protegens strain L21 & MT505104.1 & $98.8 \%$ \\
\hline E6 & Pseudomonas gessardii strain TsPm1_A & MT605326.1 & $100 \%$ \\
\hline E7 & Pseudomonas fluorescens strain G7 & CP027561.1 & $99.3 \%$ \\
\hline E8 & Aeromonas salmonicida strain A1 & MT576565.1 & $99.9 \%$ \\
\hline E10 & Pseudomonas koreensis strain SS NBRI 17 & MT629852.1 & $100 \%$ \\
\hline E11 & Serratia fonticola strain biosolid & CP054160.1 & $98.8 \%$ \\
\hline E12 & Pseudomonas putida strain SeaQual P_B75 & MT626824.1 & $100 \%$ \\
\hline E13 & Aeromonas sp. Strain L4 & MT516456.1 & $99.7 \%$ \\
\hline
\end{tabular}

All isolated bacteria species has been reported previously in natural water sources [46], [47], [48]. In accordance with our results, previous studies have demonstrated that Pseudomonas is the most abundant genus in similar sample types [49], [50]. The aerobic denitrifying ability reported in Pseudomonas spp., has been related with nitrate pollution, a common chemical alteration mainly associated to anthropogenic activities [51]. The genus Psychrobacter is a group with a broad environmental distribution [47] and has been characterized as psychrotolerant and halotolerant [52], even reporting their association with common antimicrobial pollution [53]. Meanwhile, the Aeromonas species has been related with antibiotic pollution in aquatic environments increasing the number of antibiotic-resistant strains [54].

\section{CONCLUSIONS}

Temporality and spatial distribution on sample points play an important role in biological and abiotic component in the basin of Toltén River. Meanwhile the temperature and conductivity showed differences by temporality effect, the $\mathrm{pH}$ variable showed a spatial distribution effect. The richness of benthonic macroinvertebrates also is affected by temporality and spatial distribution.
Although in winter the analyzed areas had similar values; in spring the values are increased in the downstream area. A similar behavior is observed on diversity and abundance. The conformation of the community allowed us to classify the water quality in class I in the spring season. However, in the winter season, it varies to class I, II and III. These variations can be triggered by various factors such as temperature, effluent and proximity to human populations where land use has an effect on water quality, which is why it is important to continue monitoring basins at various points to complement the information. obtained in this study to have a complete scenario of the behavior of the basin, its tributaries and the impact of human populations on aquatic biodiversity.

\section{ACKNOWLEDGEMENTS}

This work was funded by Universidad Autónoma de Chile, grant Enlace $\mathrm{N}^{\circ}$ UA-EN2018-16. The authors thank to Limnology laboratory at Universidad de Chile by the macroinvertebrates analysis support and the author Francisco Llanquín thanks to CONICYT-PFCHA/Magíster Nacional/2020-222015999 grant.

\section{REFERENCES}

1. P. Rajiv, H.A. Salam, M. Kamaraj, R. Sivaraj, A. Sankar. Int. Res. J. Environ Sci. 1, 1, (2012).

2. A. Singh, K.J. Thomsen, R. Sinha, J.P. Buylaert, A. Carter, D.F. Mark, P.J Mason, A.L. Densmore, A.S. Murray, M. Jain, D. Paul, S. Gupta. Nat. Commun. 8, 1617, (2017).

3. M.G. Macklin, J. Lewin. Quat. Sci. Rev. 114, (2015).

4. R. Abell, B. Lehner, M. Thieme, S. Linke. Conserv. Lett. 10, 4, (2017).

5. C.J. Vörösmarty, P.B. McIntyre, M.O. Gessner, D. Dudgeon, A. Prusevich, P. Green, S. Glidden, S.E. Bunn, C.A. Sullivan, C.R. Liermann, P.M. Davis. Nature, 467, 7315, (2010).

6. C.J. Vörösmarty, D. Lettenmaier, C. Lévêque, M. Meybeck, C. Pahl-Wostl, J. Alcamo, W. Cosgrove, H. Grassl, H. Hoff, P. Kabat, F. Lansigan, R. Lawford. Eos AGU Trans. 85, 48, (2004).

7. Lee SW, Hwang SJ, Lee SB, Hwang HS, Sung HC. Landsc. Urban Plan. 92, 2, (2009).

8. S.T.Y. Tong, W. Chen. J. Environ. Manage. 66, 4, (2002)

9. M. Alberti, D. Booth, K. Hill, B. Coburn, C. Avolio, S. Coe, D. Spirandelli. Landsc. Urban Plan. 80, (2007).

10. G. Goshu, D. Tewabe, B.T. Adugna. Ecohydrol. Hydrobiol. 10, 2-4, (2010)

11. A.K.T. Kirschner, G.H. Reischer, S. Jakwerth, D. Savio, S. Ixenmaier, E. Toth, R. Sommer, R.L. Mach, R. Linke, A. Eiler, S. Kolarevic, A.H. Farnleitner. Water Res.124, 1, (2017).

12. P.C. von der Ohe, A. Prüss, R.B. Schäfer, M. Liess, E. de Deckere, W. Brack J. Environ Monit. 9, 9, (2007).

13. G. Roldán-Pérez. Rev. la Acad. Colomb. Ciencias Exactas, Físicas y Nat. 40, 155, (2016).

14. H. Niemeyer, P. Cereceda Instituto Geográfico Militar, (1984).

15. J. Barile, M. Escudero, P. De Los Ríos-Escalante. Crustaceana, 91, 1, (2018)

16. C.E. Yoshida, V.S. Uieda. Braz. J. Biol. 74, 2, (2014).

17. K. Fiege, C.A. Miller, L.F. Robinson, R. Figueroa, B. Peucker-Ehrenbrink. Chem. Geol., 268, 3-4, (2009).

18. Dirección General de Aguas. Diagnóstico y clasificación de los cursos y cuerpos de agua según objetivos de calidad, cuenca del río Toltén, Dirección General de Aguas, Santiago, (2004).

19. R.W. Merritt and K.W. Cummins in Methods in Stream Ecology, F.R. Hauer, G.A. Lamberti eds. Academic Press Inc., San Diego, (1996; 453-474).

20. E. Domínguez, H.R. Fernández. Guía para La determinación de los artrópodos bentónicos sudamericanos. Tucumán, Universidad Nacional de Tucumán, Facultad de Ciencias Naturales e Instituto M. Lillo, (2001).

21. S. Tomanova, E. Goitia, J. Helešic. Hydrobiologia 556, 251-264, (2006)

22. H. Tachet, P. Richoux, M. Bournaud, P. Usseglio-Polatera. Invertebres d'eau Douche: Systematique, Biologie, Ecologie CNRS, Paris, (2010).

23. R. Figueroa, A. Palma, V. Ruiz, X. Niell. Rev. Chil. Hist. Nat., 80, 2, 225 242, (2007)

24. K.R. Clarke, R.N. Gorley. PRIMER v6: User Manual/Tutorial (Plymouth Routines in Multivariate Ecological Research). PRIMER-E, Plymouth, 2006.

25. M.J. Anderson, R.N. Gorley, K.R. Clarke. PERMANOVA+ for PRIMER Guide to Software and Statistical Methods, PRIMER-E, Plymouth, (2008).

26. M. Seoanez. Ecología Industrial: Ingeniería medio ambiental aplicada a la industria y a la empresa. Ediciones Mundi, España, (1995). 
27. N.R. Rivera, F. Encina, R. Palma, P. Mejias. Inf. Tecnol., 20, 4, 75-84, (2009).

28. J.C. Arroyo, A.C. Encalada. Av. Cienc. Ing. 1, 11-16, (2009).

29. INN. Norma chilena (NCh) 1333. Requisitos de calidad de agua para diferentes usos. Norma Chilena Oficial, 15, (2020).

30. A.P. Urrego, J. J. Ramírez R. Caldasia, 22, 1, 127-141, (2000)

31. CADE-IDEPE consultores. Diagnóstico y Clasificación de los Cursos y Cuerpos de Agua Según Objetivos de Calidad, (2004).

32. Ingeniería \& Gestión Ambiental. Línea de Base Ambiental Central Hidroeléctrica Los Aromos, (2013).

33. A.M. Meza, J. Rubio, G. Lucimar, M. Jeymmy. Caldasia, 34, 2, 443-456, (2012).

34. P.J. Pavé, M. Marchese. Ecol. Austral, 15, 2, 183-197, (2005).

35. L. Pla. Interciencia, 31, 583-590, (2006).

36. F. Correa-Araneda, R. Rivera, J. Urrutia, P. Rios, A. Contreras, F. EncinaMontoya. Limnetica, 29, 2, 183-194, (2010).

37. A. Yépez-Rosado, Á. Yanez, J. Urdánigo, D. Cabezas, N. Chuez, C. Cajas. Ciencias Ambientales, 10, 27-34, (2017).

38. M. Ferrú, P. Fierro. IDESIA, 33, 4, 47-54, (2015).

39. J. Iannacone, J. Mansilla, K. Ventura. Ecol. Apl., 2, 1, 116-124, (2003).

40. E. Morelli, A. Verdi. Rev. Mex. Biodivers. 85, 4, 1160-1170, (2014).

41. M. Silva Poma, A. Huamantinco Araujo. Limnetica, 41, 1, (2022).

42. N. Valverde, O. Caicedo, N. Aguirre. Producción + Limpia, 4, 1, 44-59, (2009).
43. G.M. Luna, A. Dell'Anno, B. Pietrangeli, R. Danovaro. J. Biotechnol. 157, 4, (2012).

44. X.M. Su, S. Zhang, R. Mei, Y. Zhang, M.Z. Hashmi, J. Liu, H. Lin, L. Ding, F. Sun. Microb. Biotechnol. 11, 3, (2018).

45. P.H. Janssen. Appl. Environ. Microbiol. 72, 3, (2006).

46. N. R. Ward, R.L. Wolfe, C.A. Justice, B.H. Olson. Adv. Appl. Microbiol. 31, (1986).

47. M.L.García-López, J.A. Santos, A. Otero, J.M. Rodríguez-Calleja. Psychrobacter. Encyclopedia of Food Microbiology 261-268, (2014).

48. A.A. Gavriel, J.P. Landre, A.J. Lamb. J. Appl. Microbiol. 84, 383-392, (1998).

49. C. Kittinger, M. Lipp, B. Folli, A. Kirschner, R. Baumert, H. Galler, A.J. Grisold, J. Luxner, M. Weissenbacher, A.H. Farnleitner, G. Zarfel. PLoS One 11, 11, (2016).

50. D.K. Welter, A. Ruaud, Z.M. Henseler, H.N. De Jong, P. van Coeverden de Groot, J. Michaux, L. Gormezano, J.L. Waters, N.D. Youngblut, R.E. Ley. bioRxiv, 10.23.352302, (2020).

51. R. Infascelli, R. Pelorosso, Boccia, L. Geospat. Health, 4, 27-38, (2009)

52. J.R. Huddleston, J.C. Zak, R.M. Jeter. Appl. Environ. Microbiol. 72, (11), 7036-7042, (2006).

53. M. Harnisz, I. Gołaś, Pietruk, M. Ecol. Indic. 11, 663-668, (2011).

54. S. Baron, S.A. Granier, E. Larvor, E. Jouy, M. Cineux, A. Wilhelm, B. Gassilloud, S. Le Bouquin, I. Kempf, C. Chauvin. Front. Microbiol. 8, 503, (2017) 